\title{
Quantitative Characterization for the Micronanopore Structures of Terrestrial Shales with Different Lithofacies Types: A Case Study of the Jurassic Lianggaoshan Formation in the Southeastern Sichuan Basin of the Yangtze Region
}

\author{
Weiwei Liu, ${ }^{1,2,3}$ Kun Zhang $\mathbb{D}^{4,5,6}$ Qianwen Li, ${ }^{1,7}$ Zhanhai Yu, ${ }^{8}$ Sihong Cheng, ${ }^{2}$ Jiayi Liu, \\ Pei Liu, ${ }^{4,5}$ Fengli Han, ${ }^{4,5}$ Liangyi Tang, ${ }^{4,5}$ Zhengwei Li, ${ }^{9}$ Xuejiao Yuan, ${ }^{4,5}$ Yiming Yang, ${ }^{4,5}$ \\ Yao Zeng, ${ }^{4,5}$ and Chen Zhang ${ }^{10,11}$ \\ ${ }^{1}$ State Key Laboratory of Shale Oil and Gas Enrichment Mechanisms and Effective Development, Beijing 100083, China \\ ${ }^{2}$ Jiangxi Provincial Shale Gas Investment Company, Ltd., Nanchang 330000, China \\ ${ }^{3}$ Jiangxi Provincial Natural Gas Group Company, Ltd., Nanchang 330000, China \\ ${ }^{4}$ School of Geoscience and Technology, Southwest Petroleum University, Chengdu 610500, China \\ ${ }^{5}$ State Key Laboratory of Oil and Gas Reservoir Geology and Exploitation, Southwest Petroleum University, Chengdu 610500, China \\ ${ }^{6}$ Key Laboratory of Tectonics and Petroleum Resources (China University of Geosciences), Ministry of Education, \\ Wuhan 430074, China \\ ${ }^{7}$ Sinopec Petroleum Exploration and Production Research Institute, Beijing 100083, China \\ ${ }^{8}$ PetroChina Changqing Oilfield Exploration and Development Research Institute, Xi'an 710018, China \\ ${ }^{9}$ School of Environment and Resource, Southwest University of Science and Technology, Mianyang 621010, China \\ ${ }^{10}$ State Key Laboratory of Petroleum Resources and Prospecting, China University of Petroleum, Beijing 102249, China \\ ${ }^{11}$ College of Geoscience, China University of Petroleum, Beijing, China
}

Correspondence should be addressed to Kun Zhang; shandongzhangkun@126.com

Received 25 September 2021; Accepted 20 November 2021; Published 1 December 2021

Academic Editor: Jing Wu

Copyright (c) 2021 Weiwei Liu et al. This is an open access article distributed under the Creative Commons Attribution License, which permits unrestricted use, distribution, and reproduction in any medium, provided the original work is properly cited.

Due to the specificity of the geological background, terrestrial strata are widely distributed in the major hydrocarbon-bearing basins in China. In addition, terrestrial shales are generally featured with high thickness, multiple layers, high TOC content, ideal organic matter types, and moderate thermal evolution, laying a solid material foundation for hydrocarbon generation. However, the quantitative characterization study on their pore structure remains inadequate. In this study, core samples were selected from the Middle Jurassic Lianggaoshan Formation in the southeastern Sichuan Basin of the Upper Yangtze Region for analyses on its TOC content and mineral composition. Besides, experiments including oil washing, the adsorption/desorption of $\mathrm{CO}_{2}$ and nitrogen, and high-pressure mercury pressure experiments were carried out. The pore structure of different petrographic types of terrestrial shales can be accurately and quantitatively characterized with these works. The following conclusions were drawn: for organic-rich mixed shales and organic-rich clay shales, the TOC content is the highest; the pore volume, which is primarily provided by macropores and specific surface area, which is provided by mesopores, was the largest, thus providing more space for shale oil and gas reservation. The pores take on a shape either close to a parallel plate slit or close to or of an ink bottle. For organic-matter-bearing shales, both the pore volume and specific surface area are the secondlargest and are provided by the same sized pores with organic-rich mixed shales. Its pores take on a shape approximating either a parallel plate slit or an ink bottle. Organic-matter-bearing mixed shales have the lowest pore volume and specific surface area; its pore volume is primarily provided by macropores, and the specific surface area by mesopores and the shape of the pores are close to an ink bottle. 


\section{Introduction}

In recent years, thanks to the development of the unconventional oil and gas theory, significant breakthroughs have been made in exploring and exploiting marine shale gas in China [1-5]. Similarly, terrestrial strata are widely distributed in the hydrocarbon-bearing basins. Terrestrial shales are of good kerogen type and are characterized by wide distribution, high thickness, multiple layers, high TOC content, and moderate thermal evolution [6-12]. All the major oil companies of China have begun to pay great attention to the geological research of terrestrial shale oil and gas, with more investment being made during the 14th Five-Year Plan period [13-15].

Shale pores provide the main preservation space and seepage channels for shale oil and gas [16-18]. Therefore, it is critical to find the appropriate approach for conducting studies on shale pore characteristics. Previous researchers have carried out various experiments, including nuclear magnetic resonance, $\mathrm{CO}_{2}$ adsorption, $\mathrm{N}_{2}$ adsorption, highpressure mercury compression, and spontaneous percolation, to quantitatively characterize the shale pore's structural characteristics [19-25]. Besides, these characteristics were also observed directly using scanning electron microscopy and nano-CT. Ji et al. studied the shales of the Lower Silurian Longmaxi Formation from the Chongqing region in the southeastern Sichuan Basin and discussed the micronanopore pore structure characteristics of marine shale reservoirs and their controlling factors with the help of field emission scanning electron microscope (FE-SEM) and by $\mathrm{CO}_{2}$ and $\mathrm{N}_{2}$ low-temperature and low-pressure adsorption experiments [26]. Li et al. qualitatively and quantitatively characterized the micro- and nanopore structures of the $\mathrm{Es}_{3}{ }^{1}$ terrestrial shale reservoir in the Zhanhua Depression by FE-SEM as well as the experiments of $\mathrm{CO}_{2}$ and $\mathrm{N}_{2}$ adsorptions and high-pressure mercury compression. The results showed that the terrestrial shale from the lower submember of the 3rd member of the Eocene Shahejie Formation in the Zhanhua Depression has four types of pores: organic-matter pore, intergranular pore, intragranular pore, and microfracture. Micropores, mesopores, and macropores are all developed in the shale. Macropores provide much more pore volume than the other two and act as the main preservation space and seepage channels for shale oil. In contrast, micropores have an absolute advantage in terms of specific surface area and are the main sites for shale oil adsorption [27]. Using the methods including FESEM, $\mathrm{CO}_{2}$ adsorption, $\mathrm{N}_{2}$ adsorption and high-pressure mercury analysis, and Soxhlet extraction, Li et al. carried out in-depth analyses on the difference between the terrestrial and marine shale reservoirs in the pore structure with the terrestrial shale reservoirs from the lower submember of the 3rd member of the Eocene Shahejie Formation in the Zhanhua Depression and the marine shale reservoirs from the Longmaxi Formation in the southeastern Sichuan as typical examples [28]. Wang et al. studied the shale samples from the Longmaxi and the Niutitang Formations located at the perimeter of Chongqing, respectively, to find out the organic-matter porosity and evolution characteris- tics of the two sets of shales herein by organic carbon content tests, whole-rock XRD analysis, equivalent vitrinite reflectance tests, FIB-SEM (focused ion beam scanning electron microscopy), and FIB-HIM (focused ion beam helium ion microscopy). Their studies also consider the strata burial history and the hydrocarbon generation evolution history [29].

Terrestrial shales of low maturity usually contain shale oil, which occupies certain pore space, resulting in inaccurate characterization using the above methods and further affecting the research on shale reservation. In this paper, oil was washed away from the terrestrial shales of different petrographic types to clear the pore space occupied by shale oil, on which bases, the joint structure characterization experiments were carried out to obtain accurate characterization results. Therefore, this research is of great theoretical and practical significance for improving the theory of shale oil formation and guiding the selection of favorable areas of exploration. This paper studied the terrestrial shales from the Middle Jurassic Lianggaoshan Formation in the southeastern Sichuan Basin of the Yangtze Region in southern China. The pore structure characteristics of the terrestrial shales with different lithofacies types in TY1 Well, which is the key exploration well, were explored (Figure 1). Besides, the shale lithofacies were firstly classified according to TOC content and mineral compositions, and then, the shale samples were washed to remove shale oil from the pores. For the washed shale samples, carbon dioxide adsorption experiments, $\mathrm{N}_{2}$ adsorption experiments, and high-pressure mercury experiments were combined to accurately characterize the real micro- and nanopore structure of shale. Their pore shapes were characterized by nitrogen adsorption/desorption experiments, based on which, the pore structure of terrestrial shales of different lithofacies was accurately and quantitatively characterized [27-31].

\section{Geological Settings}

2.1. Sedimentary and Stratum Characteristics. The underlying stratum of the Middle Jurassic Lianggaoshan Formation is the Da'anzhai Member of the Lower Jurassic Ziliujing Formation, and its overlying stratum is Member I of the Middle Jurassic Shaximiao Formation. The Lianggaoshan Formation can be divided into Members I, II, and III from the bottom to the top, and Liang Members I and II can be further divided as the upper and lower submembers [32-37]. A complete lake transgression-regression cycle occurred to the Lianggaoshan Formation before, and, from the bottom to the top. It takes on a sedimentary evolution sequence of lakeside (lower submember of Liang Member I) $\longrightarrow$ shallow lake and semideep lake facies (upper submember of Liang Member I-lower submember of Liang Member II) $\longrightarrow$ lakeside (upper submember of Liang Member II) $\longrightarrow$ delta front (Liang Member III) (Figure 2). In addition, the organic-rich dark shales are developed in the shallow lake-semi-deep lake facies of the upper submember of Liang Member I-upper submember of Liang Member II [38-42]. 


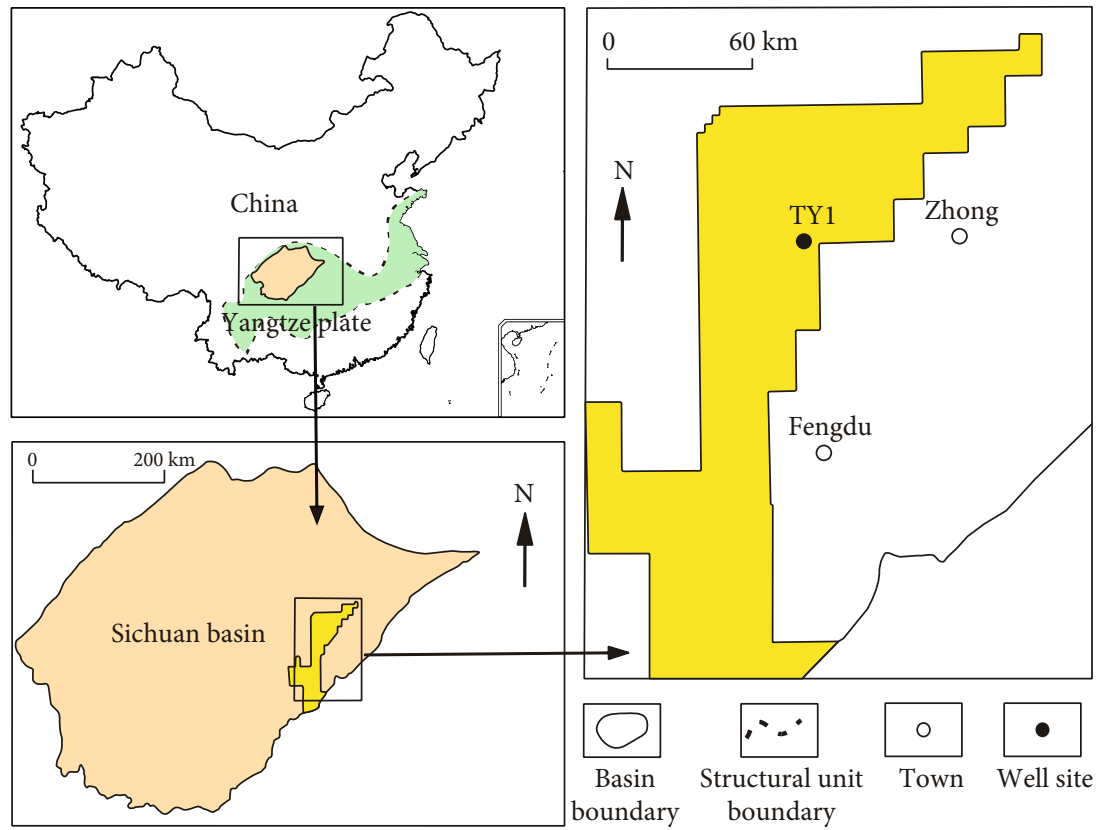

Figure 1: Location of the Southeastern Block of Sichuan Basin in Southern China and TY1 Well. Modified from references [4-8].
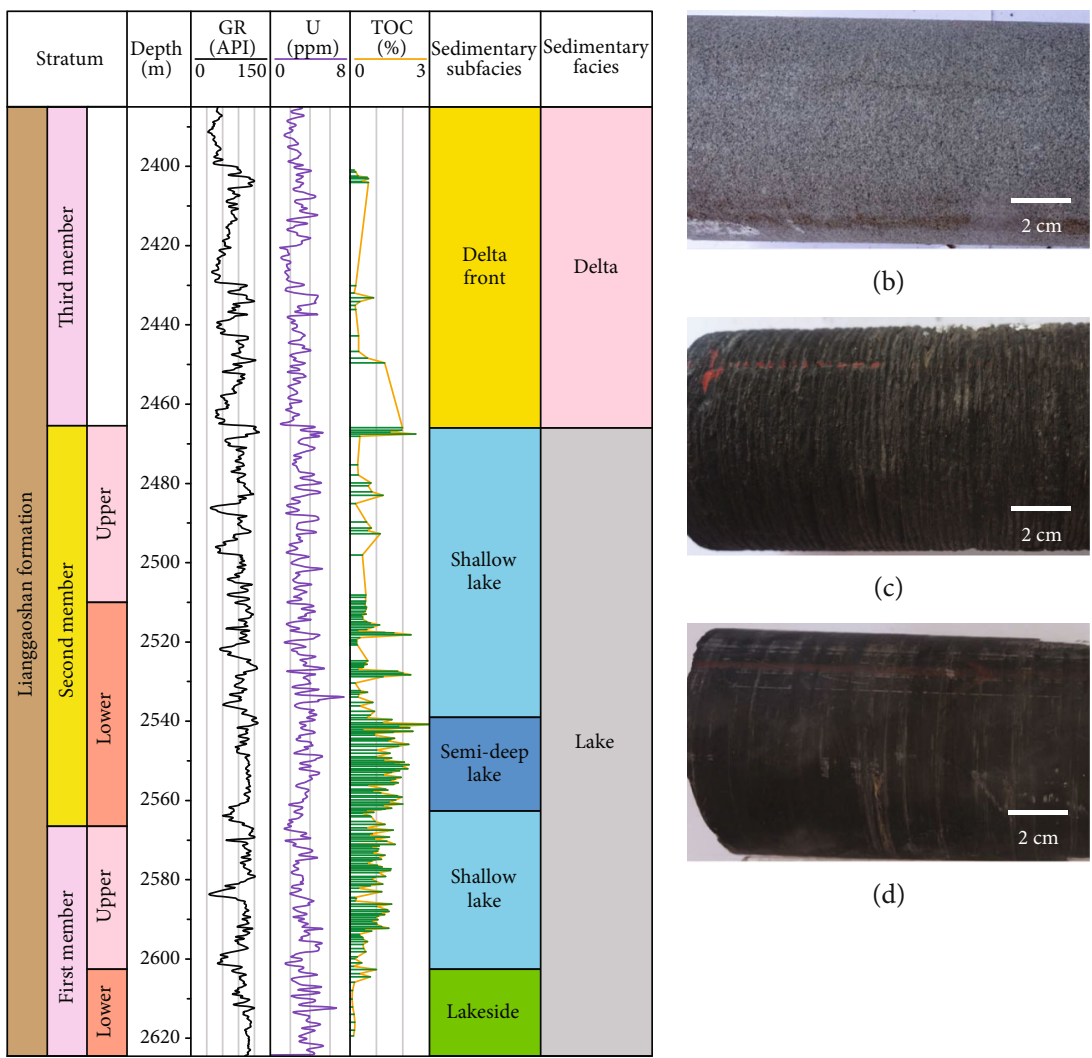

(b)

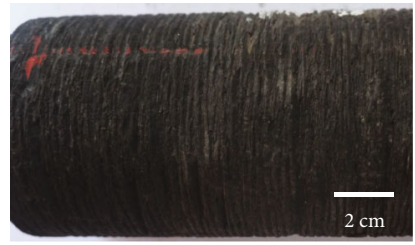

(c)

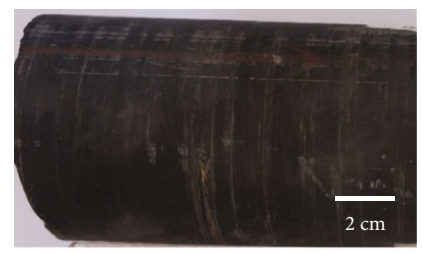

(d)

(a)

Figure 2: The comprehensive stratigraphic column diagram and core photos of the Middle Jurassic Lianggaoshan Formation in the TY1 Well. (a) The comprehensive stratigraphic column diagram of the TY1 Well. (b) Grey sandstone of the third section of the Lianggaoshan Formation, $2422 \mathrm{~m}$. (c) Grey-black shale of the lower subsection of the Liang Member II, $2542 \mathrm{~m}$. (d) Dark grey shale of the upper subsection of the Liang Member I, $2578 \mathrm{~m}$. See Figure 1 for the well locations. Modified from references [8]. 
2.2. Tectonic Characteristics. The geological structure of the southeastern Sichuan region is part of the high steep fault folds in the eastern Sichuan Basin, covering an area from east of the Huaying Mountains to west of the Qiyao Mountain [43-45]. The geological structure of such a region was mainly formed during the Himalayas age with a strong tectonic fold. There is a series of high and steep anticlines stretching from north to east and nearly parallel in the structure plan, with narrow anticlines and wide and gentle synclines [46-49]. The core of the high and steep anticlines has been exposed to the Upper Permian strata, and the Jurassic strata have been completely denudated. Moreover, it is completely preserved in the Lianggaoshan Formation of the syncline area at a depth of $500-2000 \mathrm{~m}$, and the remaining sand shale stratum of the Shaximiao Formation of several thousand meters overlying plays the role of cap rocks, providing quality conditions for oil and gas preservations $[50,51]$.

\section{Samples, Experiments, and Data Sources}

In this study, samples were taken from shales of the Lianggaoshan Formation in TY1 Well at 14 depths and were numbered as shown in Table 1. The samples from the same depth were divided into five shares and were used for TOC content analysis experiments by a Sievers 860 TOC content analyzer and for whole-rock XRD mineral analysis by a YST-I mineral analyzer. The two kinds of analyses hereinabove were used together to delineate the shale lithofacies. For the shale samples from different depths, the shale cores were first processed by oil removal with a DY-6 instrument. After removing the oil, carbon and nitrogen dioxide adsorption experiments were carried out on the shale samples using a BSD-PM1/2 and a BSD-PS1/2/4 instrument, respectively, and a $3 \mathrm{H}-2000 \mathrm{PS} 2$ instrument was used for high-pressure mercury experiments. In addition, the FIB-SEM (focused ion beam-scanning electron microscopy) experiments were carried out on shale samples of different lithofacies using an instrument (Type Helios NanoLab 660) to identify the genesis types of shale pores.

\section{Results and Discussion}

4.1. Identification of Pore Genesis Types. The pore development characteristics in the different lithofacies of the shale can be directly observed from the FIB-SEM experimental images. As can be seen from Figure 3, the pore space of the terrestrial shales in the Lianggaoshan Formation mainly develops organic matter, clay minerals, and organic matterclay mineral complexes.

4.2. Shale Lithofacies Classification. Previous studies proposed a shale lithofacies classification scheme based on the TOC content and mineral composition: (1) three types of shale based on TOC content: organic-lean shale (TOC content: $0 \%-1 \%$ ), organic shale (TOC content: $1 \%-2 \%$ ), and organic-rich shale (TOC content: $\geq 2 \%$ ); (2) four types of shale based on mineral composition: siliceous shale (siliceous minerals $\geq 50 \%$ ), clay shale (clay minerals $\geq 50 \%$ ), cal-
TABLE 1: Depths and members of samples in experiments.

\begin{tabular}{|c|c|c|}
\hline No. & $\begin{array}{l}\text { Depth of sample } \\
\qquad(\mathrm{m})\end{array}$ & Member \\
\hline 1 & 2403.93 & Liang Member III \\
\hline 2 & 2466.7 & $\begin{array}{l}\text { Upper submember of Liang Member } \\
\text { II }\end{array}$ \\
\hline 3 & 2470.82 & $\begin{array}{l}\text { Upper submember of Liang Member } \\
\text { II }\end{array}$ \\
\hline 4 & 2515.82 & $\begin{array}{l}\text { Lower submember of Liang Member } \\
\text { II }\end{array}$ \\
\hline 5 & 2527.04 & $\begin{array}{l}\text { Lower submember of Liang Member } \\
\text { II }\end{array}$ \\
\hline 6 & 2540.45 & $\begin{array}{l}\text { Lower submember of Liang Member } \\
\text { II }\end{array}$ \\
\hline 7 & 2542.24 & $\begin{array}{l}\text { Lower submember of Liang Member } \\
\text { II }\end{array}$ \\
\hline 8 & 2547.35 & $\begin{array}{l}\text { Lower submember of Liang Member } \\
\text { II }\end{array}$ \\
\hline 9 & 2552.98 & $\begin{array}{l}\text { Lower submember of Liang Member } \\
\text { II }\end{array}$ \\
\hline 10 & 2555.65 & $\begin{array}{l}\text { Lower submember of Liang Member } \\
\text { II }\end{array}$ \\
\hline 11 & 2573.32 & Upper submember of Liang Member I \\
\hline 12 & 2576.98 & Upper submember of Liang Member I \\
\hline 13 & 2579.45 & Upper submember of Liang Member I \\
\hline 14 & 2589.7 & Upper submember of Liang Member I \\
\hline
\end{tabular}

careous shale (carbonate minerals $\geq 50 \%$ ), and mixed shale (siliceous minerals, clay minerals, and carbonate minerals lower than $50 \%$ each) [52-55]. When the two groups of classifications are combined, there can be $3 \times 4=12$ types of lithofacies. The shale lithofacies classified based on the experiment results of TOC content and mineral compositions of the 14 shale samples are shown in Table 2.

4.3. Pore Structure Characteristics of Different Lithofacies Types of Shales. The shale oil existing in the shales of the Lianggaoshan Formation occupies the reservoir space in the shales, causing inaccurate pore structure characterization. In this paper, the shale samples were firstly washed to remove the shale oil from the shale pores and then characterized by carbon dioxide adsorption, nitrogen adsorption, and high-pressure mercury experiments for the distribution of micropores $(<2 \mathrm{~nm})$, mesopores $(2 \sim 50 \mathrm{~nm})$, and macropores $(>50 \mathrm{~nm})$, respectively. In addition, the pore morphology was characterized by nitrogen adsorption/desorption experiments. There are inevitably overlapping areas in the first three characterization experiments; this paper, therefore, with reference to the previous studies, deals with the pore volume and pore-specific surface area data corresponding to the overlapping area using the weighted average method [52-55]. Finally, the whole-aperture pore volume, specific surface area, and pore morphology characteristics of the 14 samples were obtained, as shown in Figures 4-6.

4.4. Pore Volume Characteristics. The occurrence space for free shale oil is characterized by the pore volume value. 


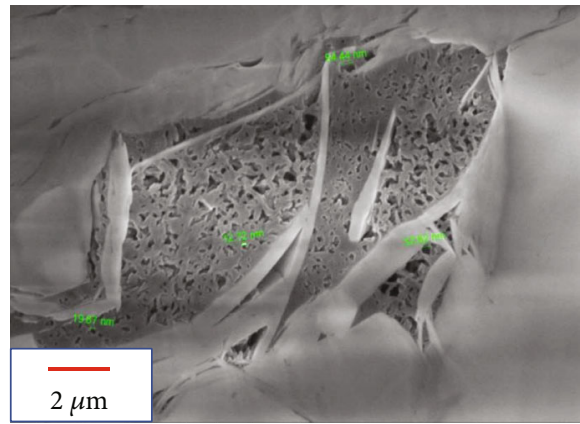

(a)

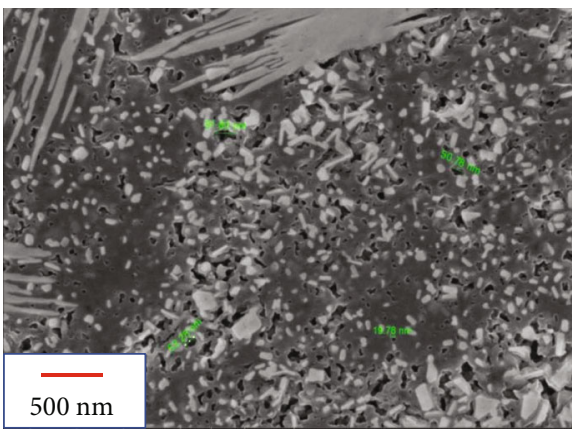

(c)

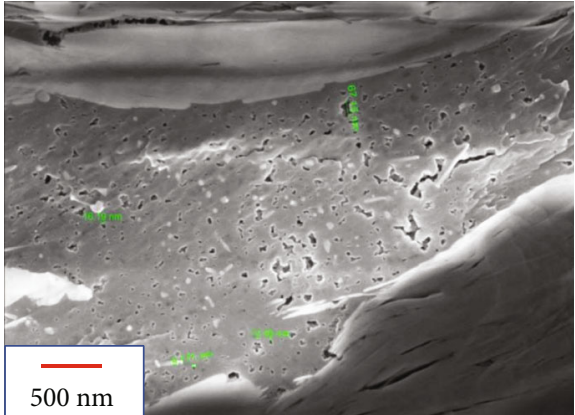

(b)

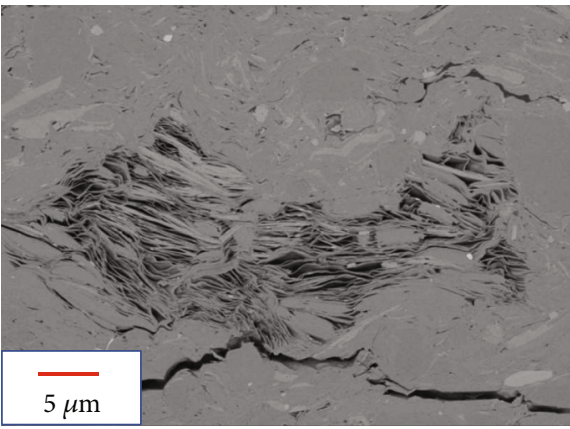

(d)

Figure 3: FIB-SEM images of the shales of the Lianggaoshan Formation, with pore genesis types identified: (a) Organic matter pore, $2547.26 \mathrm{~m}$, lower subsection of the Liang Member II; (b) organic matter pore, $2555.56 \mathrm{~m}$, lower subsection of the Liang Member II; (c) organic matter-clay mineral complex pore, $2589.61 \mathrm{~m}$, upper subsection of the Liang Member I; (d) clay mineral pore $2483.01 \mathrm{~m}$, upper subsection of the Liang Member II.

TABLE 2: Lithofacies classification of shale samples.

\begin{tabular}{lcc}
\hline No. & Depth of sample $(\mathrm{m})$ & Lithofacies \\
\hline 1 & 2403.93 & Organic-matter-bearing mixed shale \\
2 & 2466.7 & Organic-rich clay shale \\
3 & 2470.82 & Fine sandstone \\
4 & 2515.82 & Organic-matter-bearing clay shale \\
5 & 2527.04 & Organic-rich clay shale \\
6 & 2540.45 & Organic-rich clay shale \\
7 & 2542.24 & Organic-rich clay shale \\
8 & 2547.35 & Organic-rich mixed shale \\
9 & 2552.98 & Organic-rich clay shale \\
10 & 2555.65 & Organic-rich clay shale \\
11 & 2573.32 & Organic-rich mixed shale \\
12 & 2576.98 & Organic-matter-bearing clay shale \\
13 & 2579.45 & Organic-matter-bearing clay shale \\
14 & 2589.7 & Organic-matter-bearing clay shale \\
\hline
\end{tabular}

The data of pore volume characteristics hereinabove are summarized in Figure 7 (a). The organic-rich mixed shale and organic-rich clay shale have the highest pore volume at around $0.03 \mathrm{ml} / \mathrm{g}$, the fine sandstone has the secondhighest at around $0.025 \mathrm{ml} / \mathrm{g}$, the organic-matter-bearing clay shale has relatively lower pore volume at around $0.02 \mathrm{ml} / \mathrm{g}$, and the organic-matter-bearing mixed shale has the lowest at around $0.013 \mathrm{ml} / \mathrm{g}$. As shown in Figures $7(\mathrm{~b})-$ $7(d)$, macropores are the main contributor to the pore volume of each lithofacies (50\%-60\%), followed by mesopores (about 40\%).

4.5. Pore-Specific Surface Area Characteristics. The occurrence space of shale oil in the adsorbed state is characterized by the pore-specific surface area values. The data of porespecific surface area characteristics hereinabove were summarized, as shown in Figure 8(a). It can be seen that the organic-rich clay shale has the highest pore-specific surface area of about $12 \mathrm{~m}^{2} / \mathrm{g}$. The pore-specific surface areas of the organic-rich mixed shale, organic-matter-bearing clay shale, and fine sandstone are around $10 \mathrm{~m}^{2} / \mathrm{g}$. Additionally, the pore-specific surface area of the organic-matter-bearing mixed shale is about $6.5 \mathrm{~m}^{2} / \mathrm{g}$, which is the lowest. As shown in Figures $8(\mathrm{~b})-8(\mathrm{~d})$, the specific surface area of each lithofacies is mainly provided by mesopores (60\% to $90 \%$ ) followed by micropores ( $5 \%$ to $40 \%$ ).

4.6. Pore Morphology Characteristics of Shale Oil Reservoir. The actual shapes of shale pores present themselves after the shale oil was washed away [56-61]. The hysteresis loop characteristics formed by the nitrogen adsorptiondesorption isothermal curves in Figure 6 were compared with the hysteresis loop classification, and its corresponding pore morphology characteristics were classified by the International Union of Pure and Applied Chemistry (IUPAC) [62-73]. Based on the difference in pore curvature, this study further classified parallel-plate-slit pores and ink- 


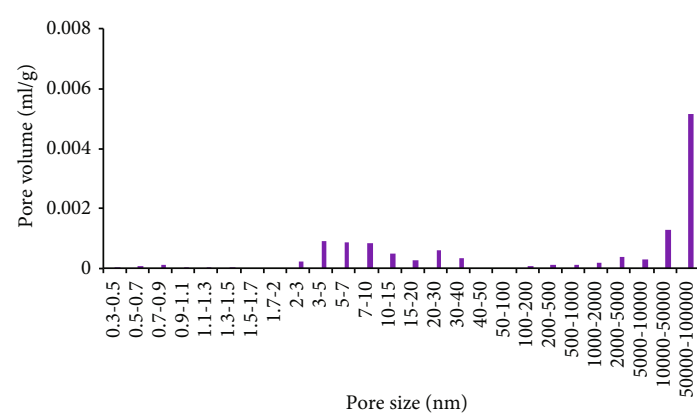

(a) $2403.93 \mathrm{~m}$, organic-matter-bearing mixed shale

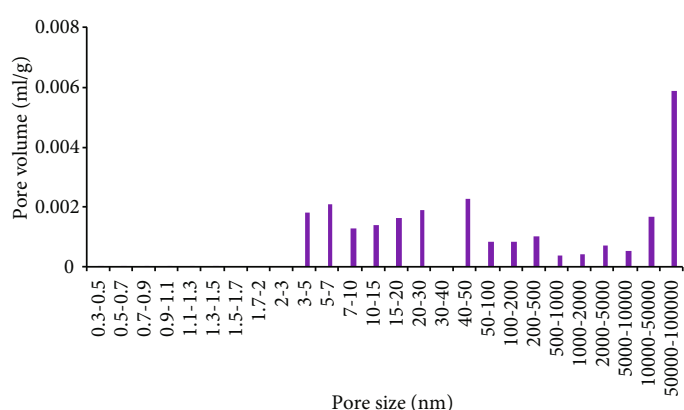

(c) $2470.82 \mathrm{~m}$, fine sandstone

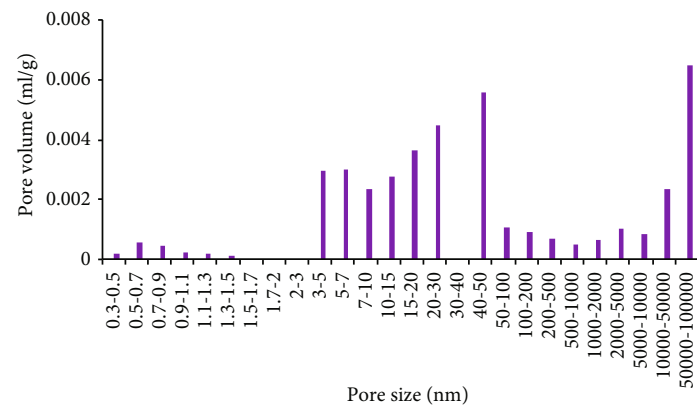

(e) $2527.04 \mathrm{~m}$, organic-rich clay shale

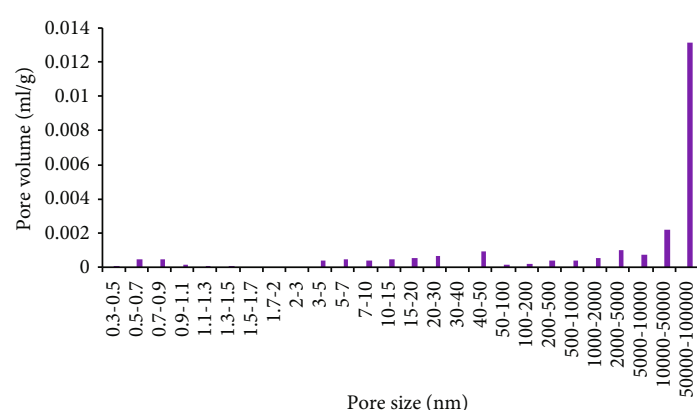

(g) $2542.24 \mathrm{~m}$, organic-rich clay shale

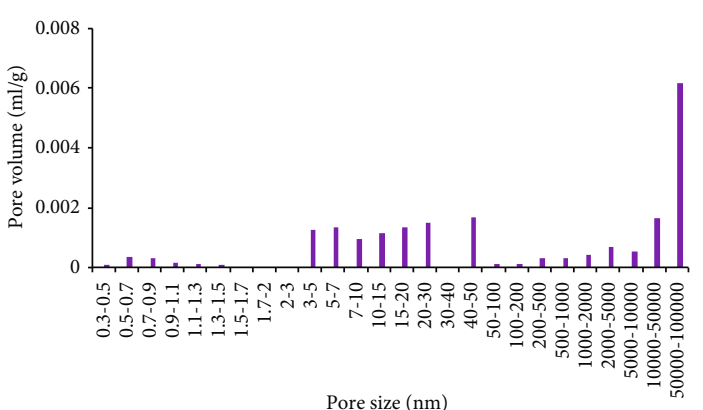

(b) $2466.7 \mathrm{~m}$, organic-rich clay shale

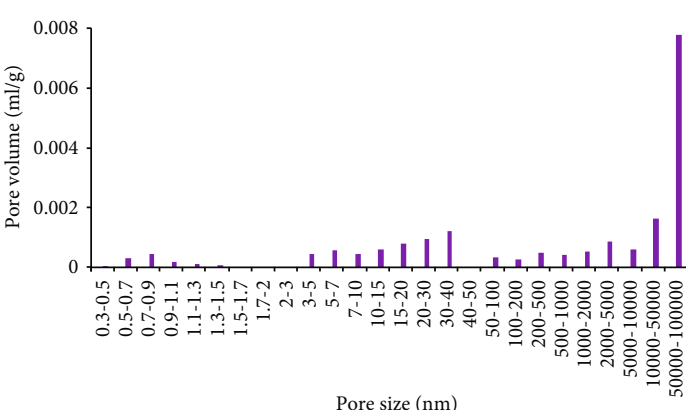

(d) $2515.82 \mathrm{~m}$, organic-matter-bearing clay shale

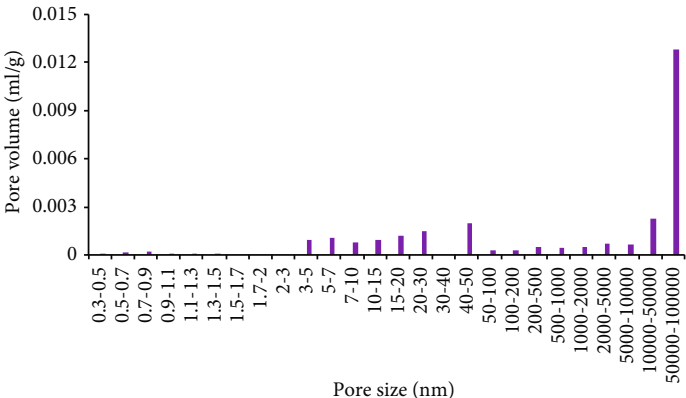

(f) $2540.45 \mathrm{~m}$, organic-rich clay shale

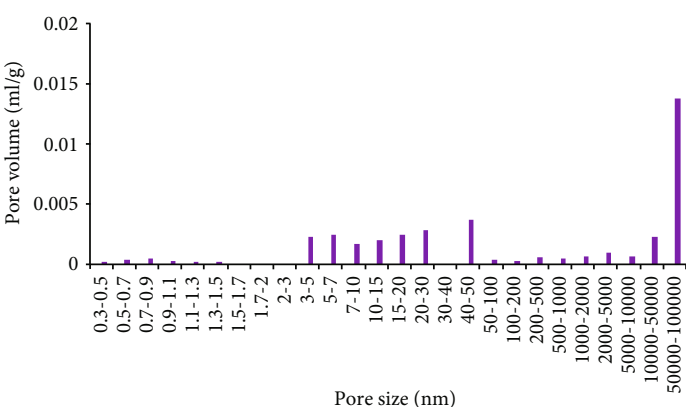

(h) $2547.35 \mathrm{~m}$, organic-rich mixed shale

FIgURE 4: Continued. 


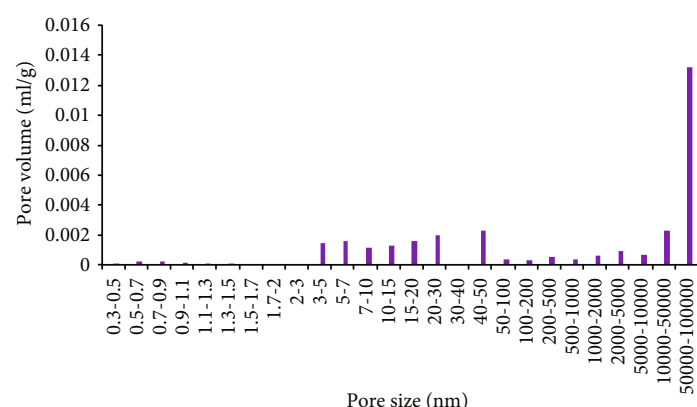

(i) $2552.98 \mathrm{~m}$, organic-rich clay shale

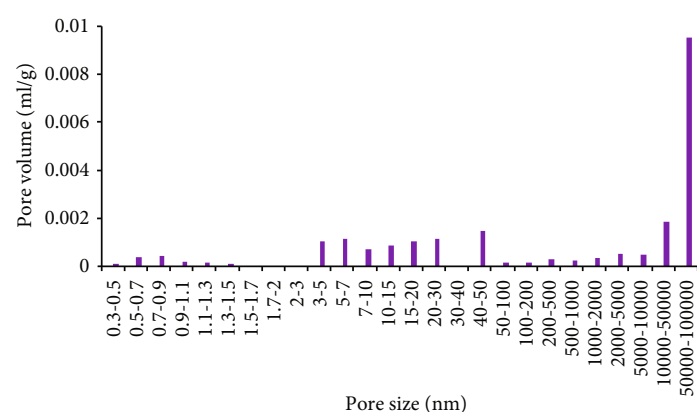

(k) $2573.32 \mathrm{~m}$, organic-rich mixed shale

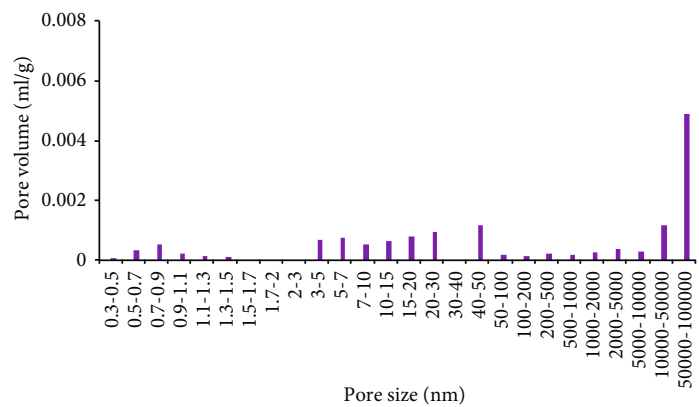

(m) $2579.45 \mathrm{~m}$, organic-matter-bearing clay shale

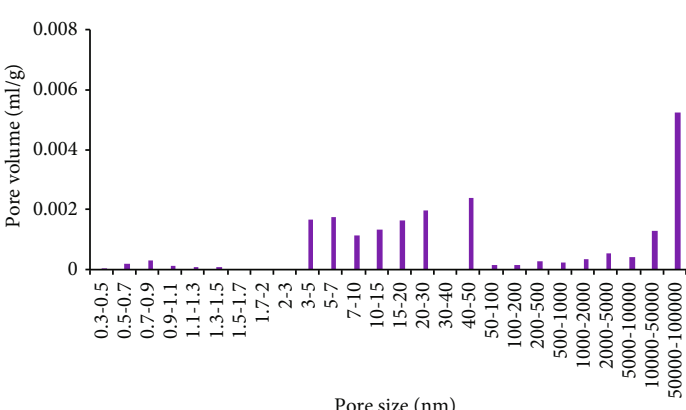

(j) $2555.65 \mathrm{~m}$, organic-rich clay shale

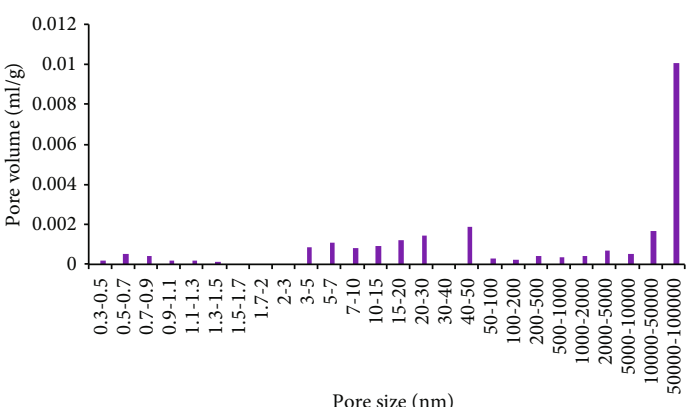

(l) $2576.98 \mathrm{~m}$, organic-matter-bearing clay shale

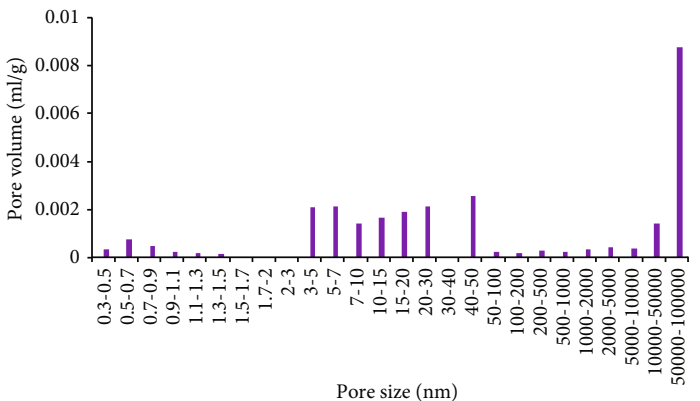

(n) $2589.7 \mathrm{~m}$, organic-matter-bearing clay shale

FIGURE 4: Pore volume characteristics of whole-aperture joint characterization of TY1 Well shale samples. 


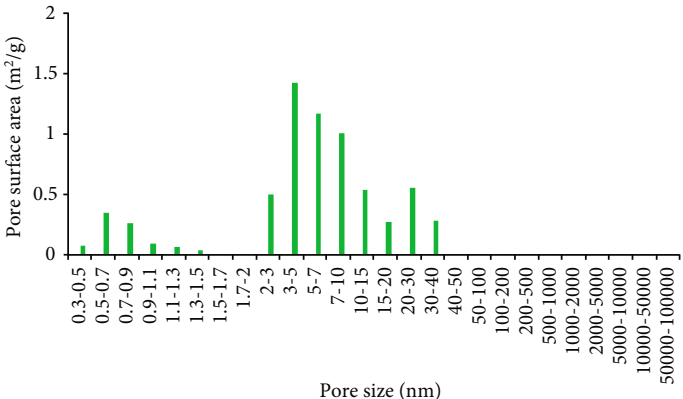

(a) $2403.93 \mathrm{~m}$, organic-matter-bearing mixed shale

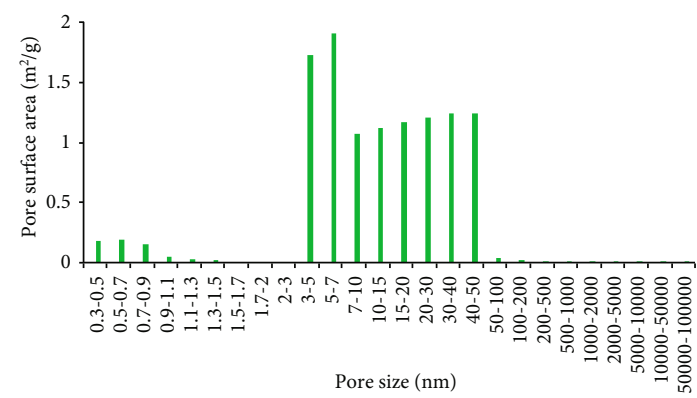

(c) $2470.82 \mathrm{~m}$, fine sandstone

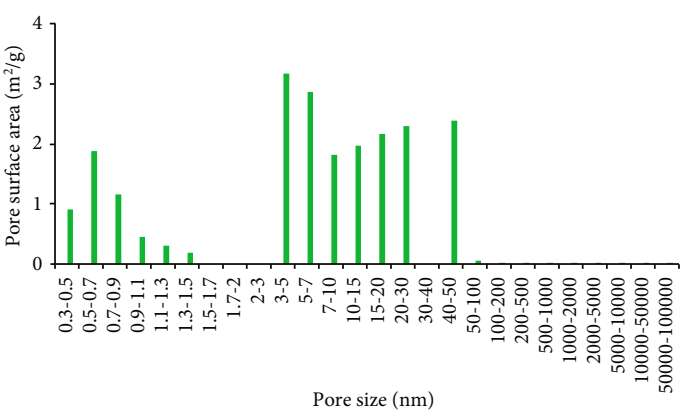

(e) $2527.04 \mathrm{~m}$, organic-rich clay shale

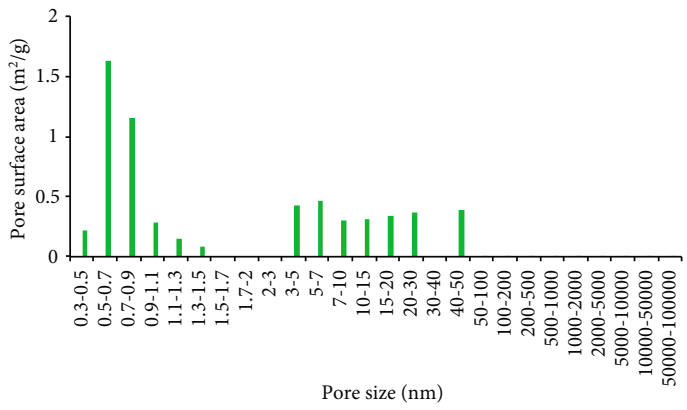

(g) $2542.24 \mathrm{~m}$, organic-rich clay shale

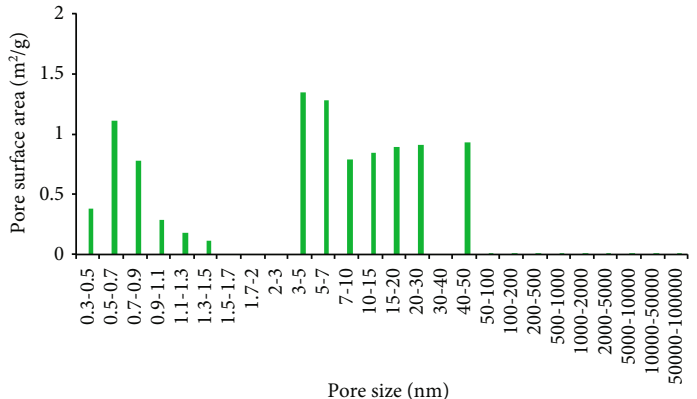

(b) $2466.7 \mathrm{~m}$, organic-rich clay shale

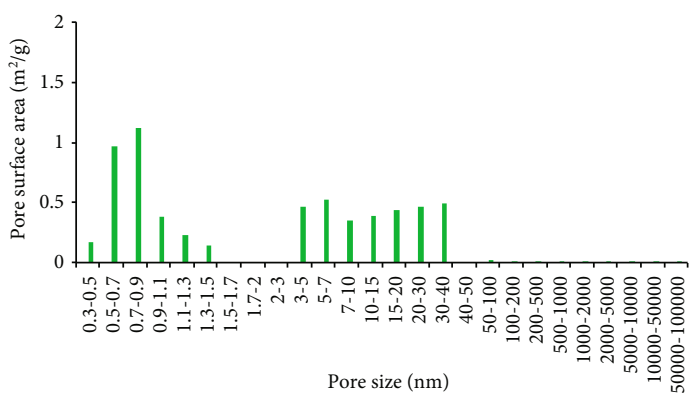

(d) $2515.82 \mathrm{~m}$, organic-matter-bearing clay shale

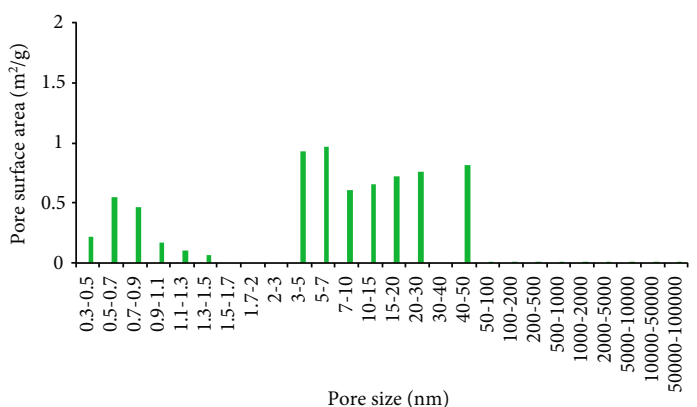

(f) $2540.45 \mathrm{~m}$, organic-rich clay shale

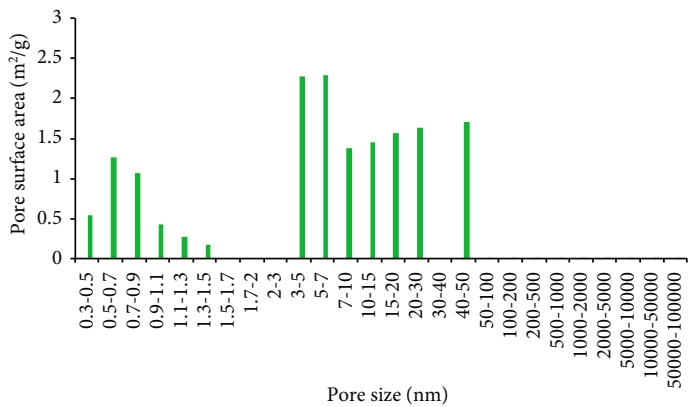

(h) $2547.35 \mathrm{~m}$, organic-rich mixed shale

Figure 5: Continued. 


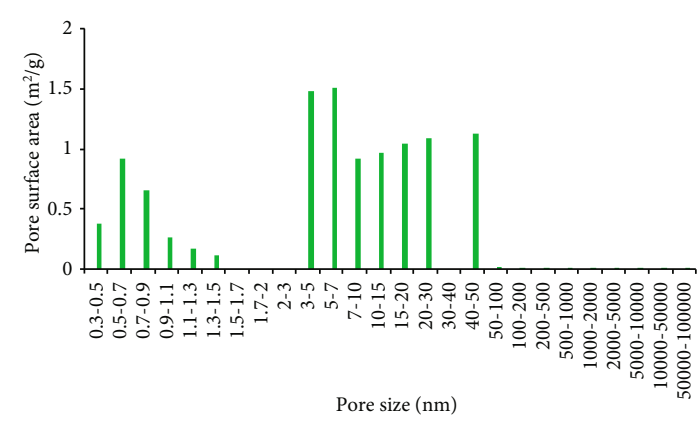

(i) $2552.98 \mathrm{~m}$, organic-rich clay shale

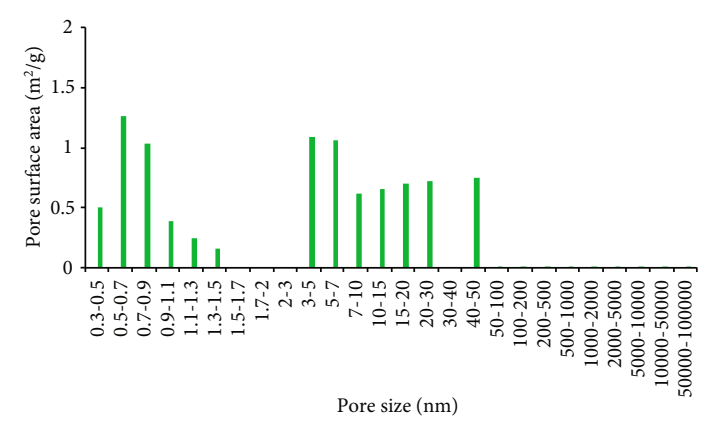

(k) $2573.32 \mathrm{~m}$, organic-rich mixed shale

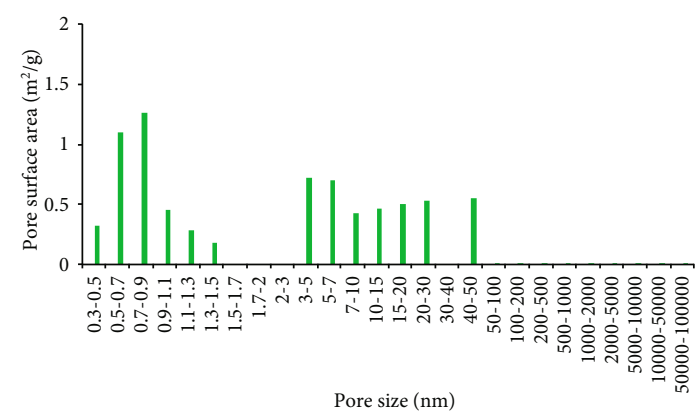

(m) $2579.45 \mathrm{~m}$, organic-matter-bearing clay shale

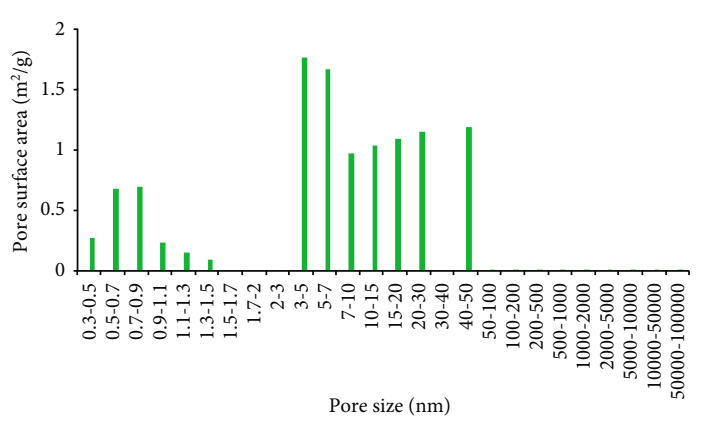

(j) $2555.65 \mathrm{~m}$, organic-rich clay shale

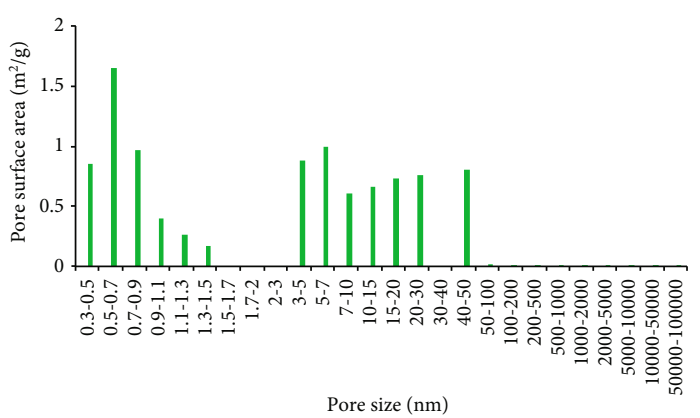

(l) $2576.98 \mathrm{~m}$, organic-matter-bearing clay shale

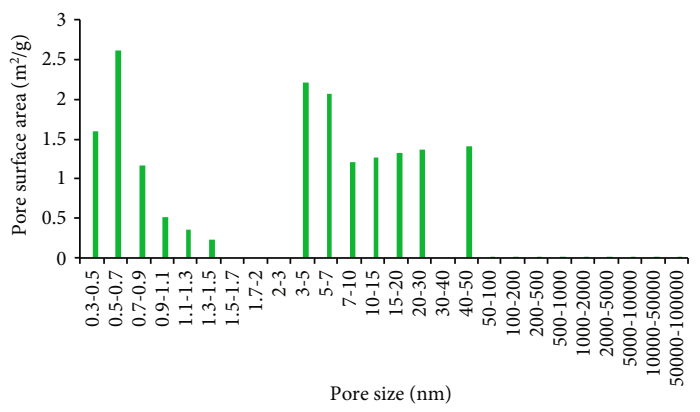

(n) $2589.7 \mathrm{~m}$, organic-matter-bearing clay shale

FIGURE 5: Specific surface area characteristics of whole-aperture joint characterization of TY1 Well shale samples. 


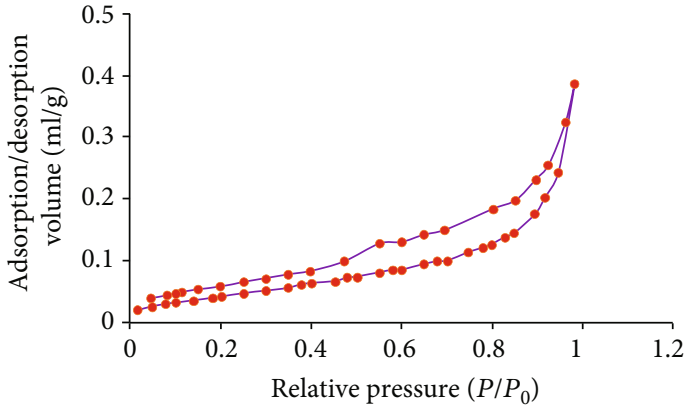

(a) $2403.93 \mathrm{~m}$, organic-matter-bearing mixed shale

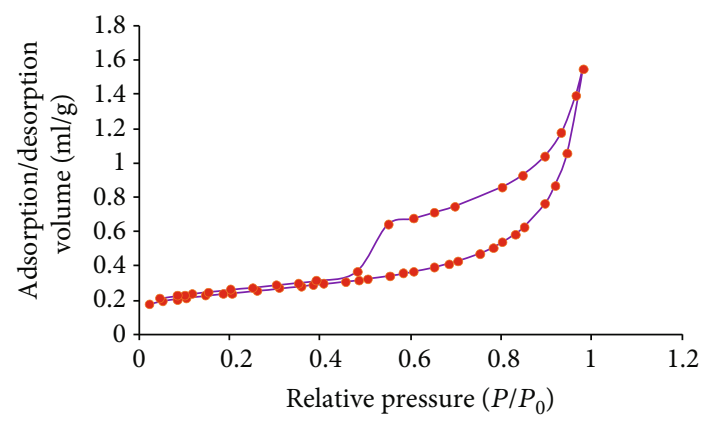

(c) $2470.82 \mathrm{~m}$, fine sandstone

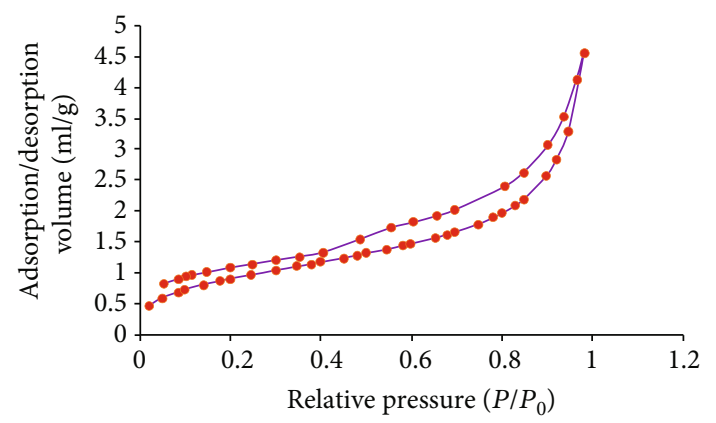

(e) $2527.04 \mathrm{~m}$, organic-rich clay shale

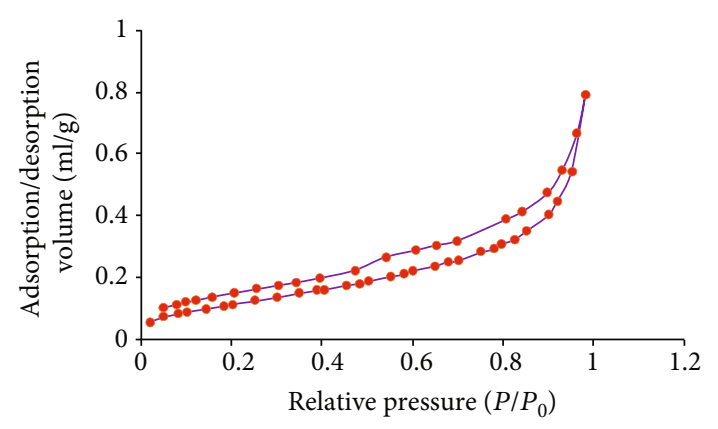

(g) $2542.24 \mathrm{~m}$, organic-rich clay shale

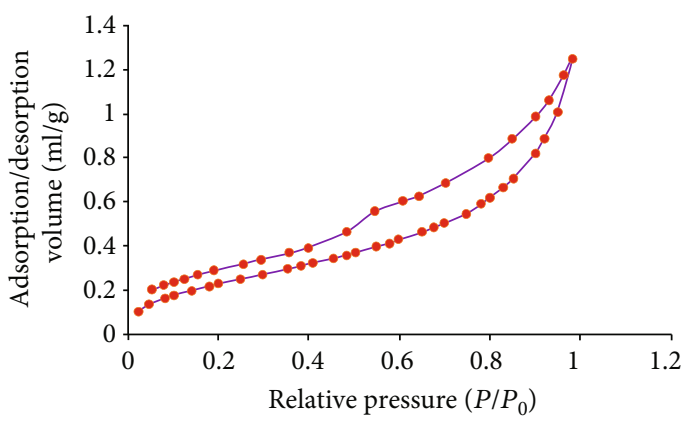

(b) $2466.7 \mathrm{~m}$, organic-rich clay shale

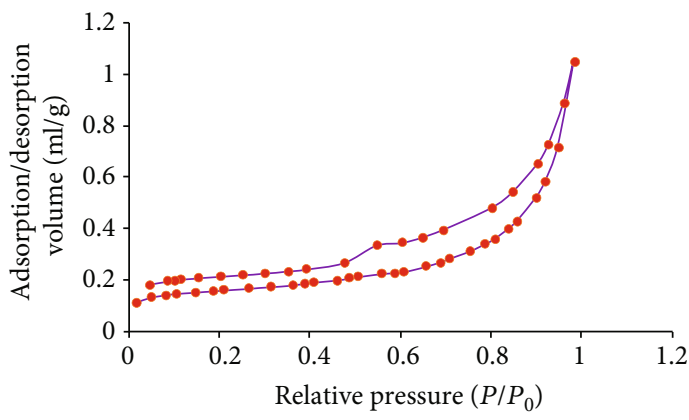

(d) $2515.82 \mathrm{~m}$, organic-matter-bearing clay shale

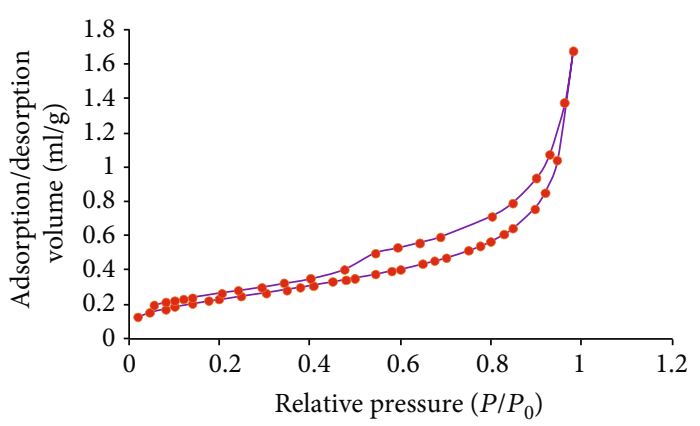

(f) $2540.45 \mathrm{~m}$, organic-rich clay shale

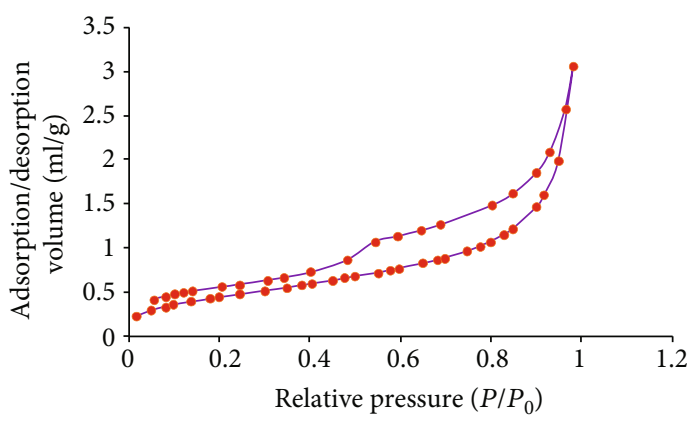

(h) $2547.35 \mathrm{~m}$, organic-rich mixed shale

Figure 6: Continued. 


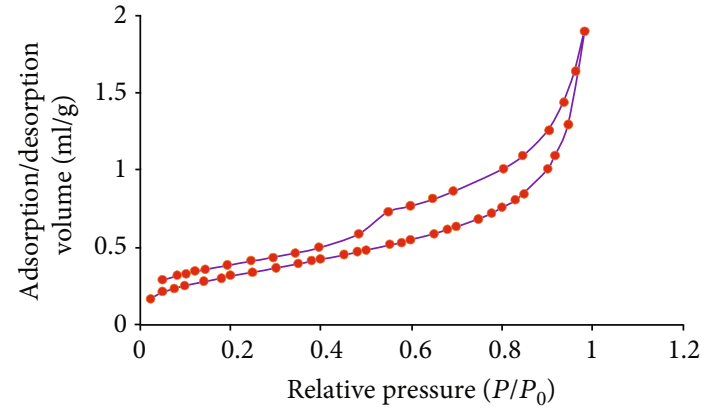

(i) $2552.98 \mathrm{~m}$, organic-rich clay shale

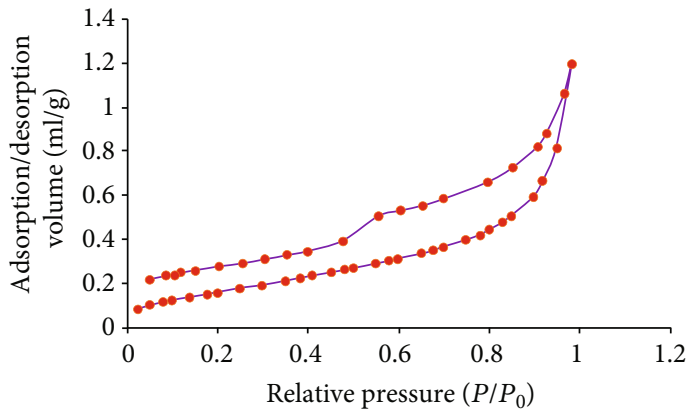

(k) $2573.32 \mathrm{~m}$, organic-rich mixed shale

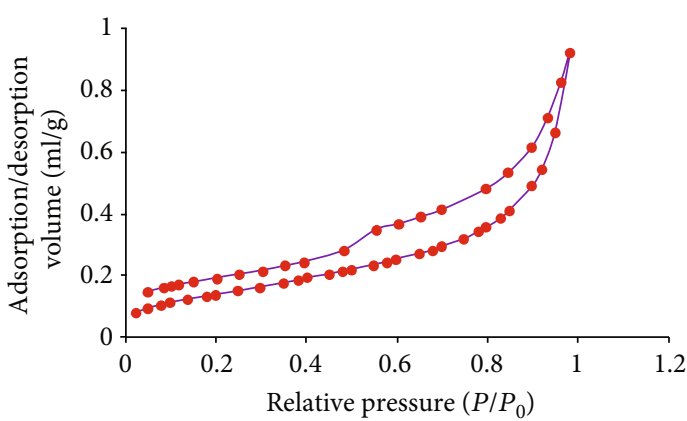

(m) $2579.45 \mathrm{~m}$, organic-matter-bearing clay shale

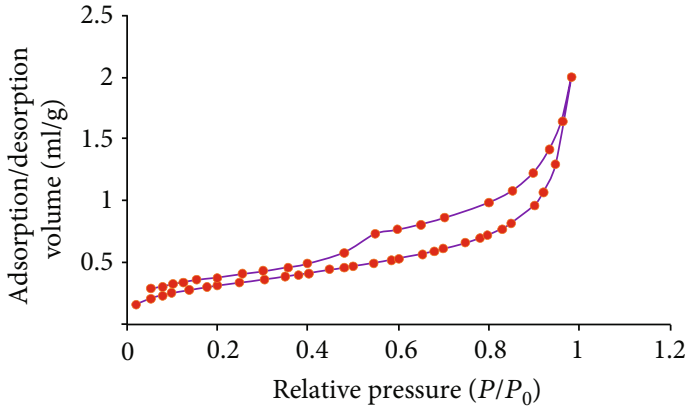

(j) $2555.65 \mathrm{~m}$, organic-rich clay shale

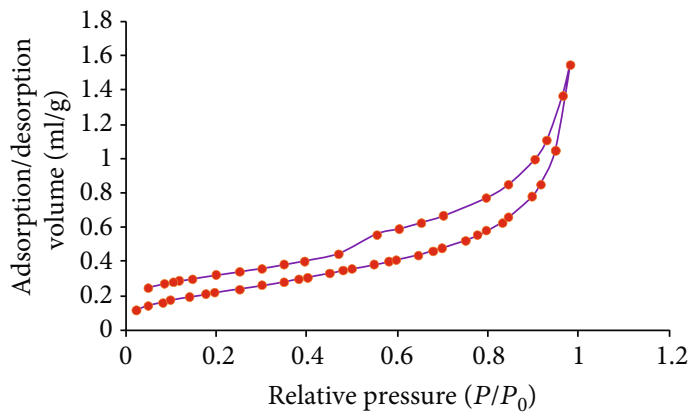

(l) $2576.98 \mathrm{~m}$, organic-matter-bearing clay shale

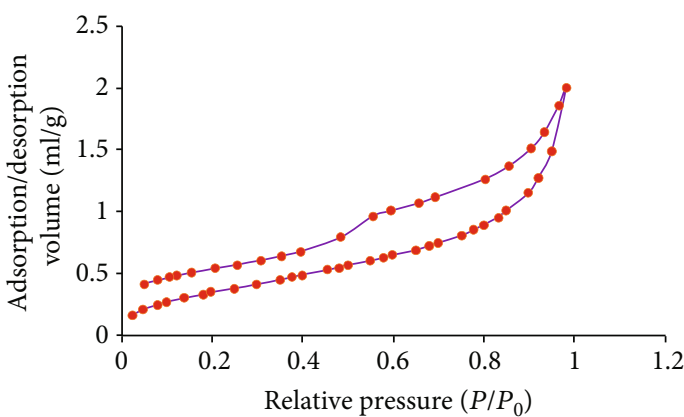

(n) $2589.7 \mathrm{~m}$, organic-matter-bearing clay shale

FIgURE 6: $\mathrm{N}_{2}$ adsorption/desorption isothermal curve of TY1 Well shale samples. 


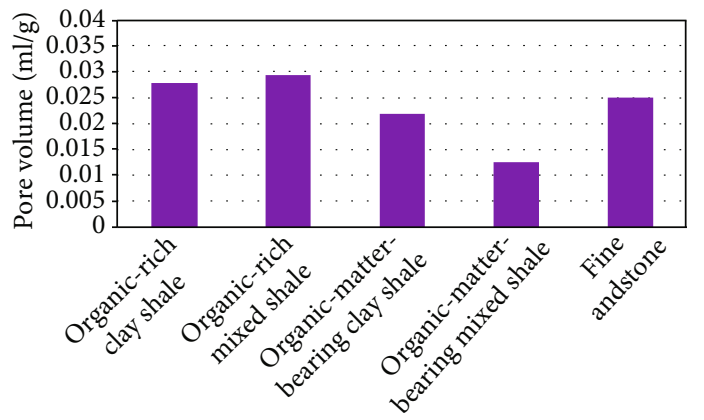

(a) Pore volume of shale reservoir of each lithofacies

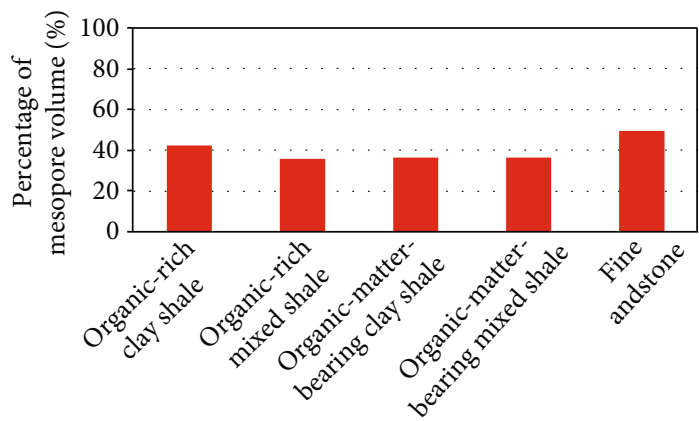

(c) Percentage of mesopore volume in the total pore volume of every lithofacies type of shale reservoir

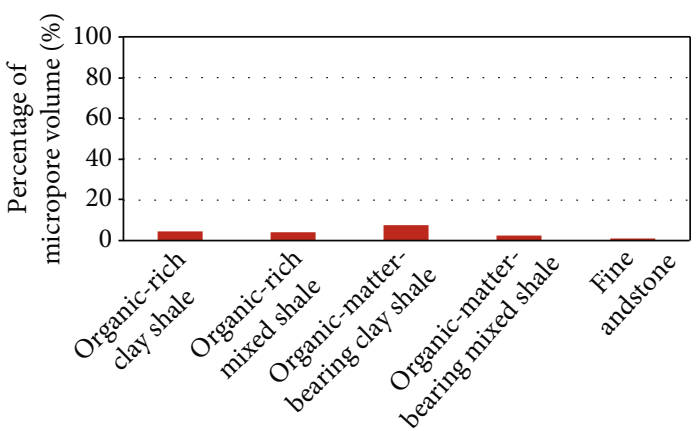

(b) Percentage of micropore volume in the total pore volume of every lithofacies type of shale reservoir

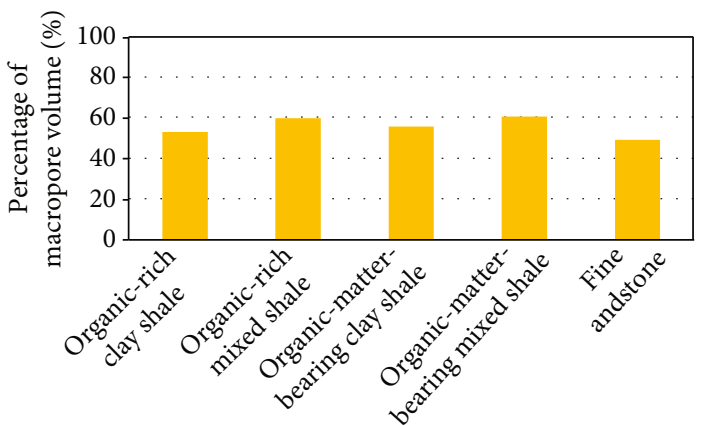

(d) Percentage of macropore volume in the total pore volume of every lithofacies type of shale reservoir

Figure 7: Pore volume characteristics of TY1 Well shale reservoirs of different lithofacies.

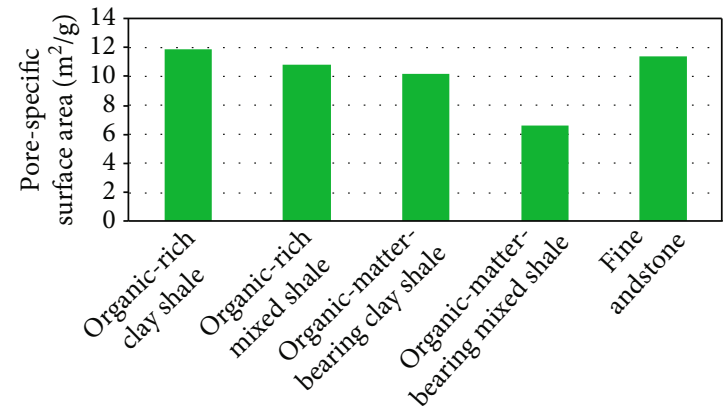

(a) Pore-specific surface area of every lithofacies type of shales

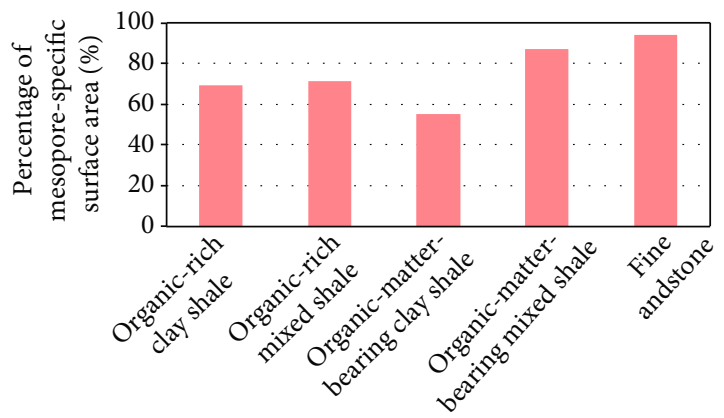

(c) Percentage of mesopore-specific surface area in total specific surface area of every lithofacies type of shale reservoir

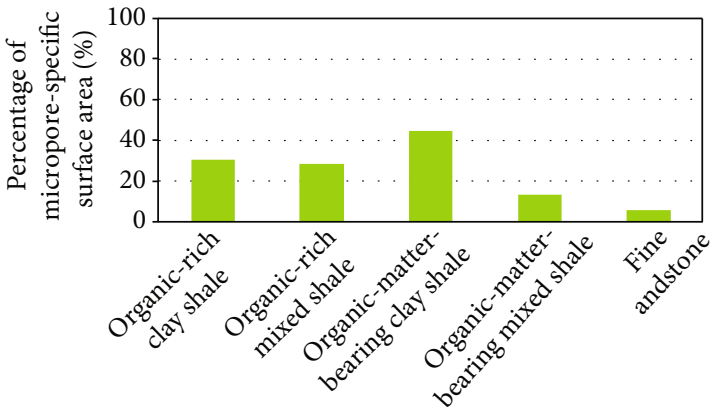

(b) Percentage of micropore-specific surface area in total specific surface area of every lithofacies type of shale reservoir

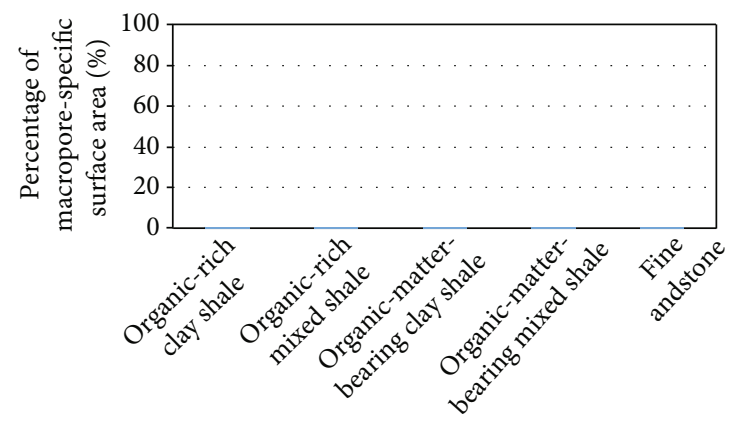

(d) Percentage of macropore-specific surface area in total specific surface area of every lithofacies type of shale reservoir

Figure 8: Pore-specific surface area characteristics of TY1 Well shale reservoirs of different lithofacies. 


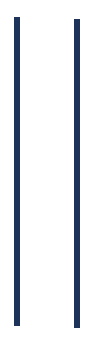

(a) Parallel-plate-slit type

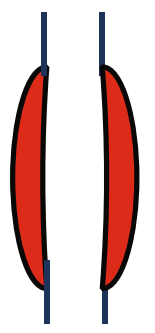

(b) Parallel-plate-slit-approximating type

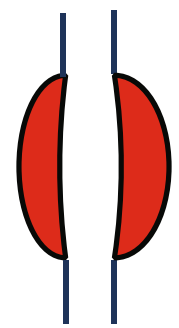

(c) Ink-bottle-approximating type

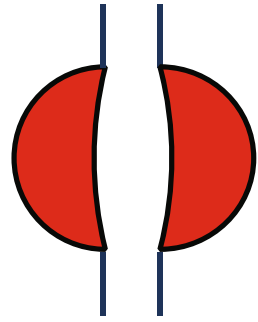

(d) Ink-bottle type

FIGURE 9: Schematic diagram of the pore morphology of shale oil reservoirs (red part as shale oil). Modified from references [62-73].

TABLE 3: Pore morphology after extracting each sedimentary microphase.

\begin{tabular}{lc}
\hline Petrography & $\begin{array}{c}\text { Pore morphology after oil } \\
\text { washing }\end{array}$ \\
\hline $\begin{array}{l}\text { Organic-matter-bearing mixed } \\
\text { shale }\end{array}$ & $\begin{array}{c}\text { Ink-bottle-approximating } \\
\text { Ink-bottle-approximating } \\
\text { Organic-matter-bearing clay } \\
\text { shale }\end{array}$ \\
$\begin{array}{cc}\text { Parallel-plate-slit- } \\
\text { approximating }\end{array}$ \\
Organic-rich mixed shale & Ink-bottle-approximating \\
Organic-rich clay shale & Ink-bottle \\
& Ink-bottle-approximating \\
Fine sandstone & $\begin{array}{c}\text { Parallel-plate-slit- } \\
\text { approximating } \\
\text { Ink-bottle }\end{array}$ \\
\hline
\end{tabular}

bottle pores by adding the shales of parallel-plate-slitapproximating type and ink-bottle-approximating type (Figure 9). After the extraction of shale oil, it was found that the pore morphologies of the organic-rich mixed shales were ink-bottle-approximating and ink-bottle types, while the organic-rich clay shales and the organic-matter-bearing clay shales were of ink-bottle-approximating and parallel-slabslit-approximating types; the organic-matter-bearing mixed shales were of ink-bottle-approximating type. Additionally, the pore morphology of the fine sandstone was of inkbottle type (Table 3 ).

\section{Conclusions}

This paper studied the shales of the Middle Jurassic Lianggaoshan Formation in the southeastern Sichuan Basin of the Upper Yangtze Region. The lithofacies of the core samples were explored based on the TOC content and mineral compositions analyses. After removing shale oil, the shale samples were then used for carbon dioxide adsorption as well as nitrogen adsorption/desorption and high-pressure mercury experiments to accurately and quantitatively characterize the pore structure of different lithofacies types of terrestrial shale. The conclusions are as follows:

(1) For shales with different lithofacies types, the reservoir characteristics vary. Organic-rich mixed shales and organic-rich clay shales have the largest pore volume and specific surface areas. Macropores are the main contributors to the pore volume, while pore-specific surface area is provided mainly by mesopores. The pore morphologies are mainly of plate-plate-slit-approximating, ink-bottle-approximating, and ink-bottle types

(2) The organic-matter-bearing clay shales have large pore volume and specific surface area. Their pore volume and pore-specific surface area are provided mainly by macropores and mesopores, respectively. The pore morphology are mainly of parallel-plate-slit-approximating and ink-bottle-approximating types

(3) The organic-matter-bearing mixed shales have smaller pore volume and specific surface area. Similar to the organic-matter-bearing clay shales, their pore volume and pore-specific surface area are provided mainly by macropores and mesopores, respectively. The pore morphology is mainly inkbottle-approximating type

\section{Data Availability}

Some of the data are contained in a published source cited in the references. All the data in this article are accessible to the readers.

\section{Conflicts of Interest}

There are no conflicts of interest concerning the results of this paper.

\section{Acknowledgments}

This study was supported by the National Natural Science Foundation of China (No. 42102192, No. 42130803, and No. 42072174), the open funds from the State Key Laboratory of Shale Oil and Gas Enrichment Mechanisms and Effective Development (G5800-20-ZS-KFGY012), the Open Fund of Key Laboratory of Tectonics and Petroleum Resources (China University of Geosciences), the Ministry of Education, Wuhan (TPR-2020-07), the open funds from the State Key Laboratory of Petroleum Resources and Prospecting (PRP/open-2107), the Science and Technology Cooperation Project of the CNPC-SWPU Innovation Alliance, and the Science Foundation of China University of Petroleum, Beijing (No. 2462020XKBH009). 


\section{References}

[1] J. B. Curtis, "Fractured shale-gas systems," AAPG Bulletin, vol. 86, no. 11, pp. 1921-1938, 2002.

[2] C. Zou, Q. Zhao, D. Dong et al., "Geological characteristics, main challenges and future prospect of shale gas," Journal of Natural Gas Geoscience, vol. 2, no. 5-6, pp. 273-288, 2017.

[3] C. Zou, Z. Yang, G. Zhang et al., "Establishment and practice of unconventional oil and gas geology," Acta Geologica Sinica, vol. 93, no. 1, pp. 12-23, 2019.

[4] X. Guo, D. Hu, Z. Wei, Y. Li, and X. Wei, "Discovery and exploration of Fuling shale gas field," China Petroleum Exploration, vol. 21, no. 3, pp. 24-37, 2016.

[5] T. Guo, "Key geological issues and main controls on accumulation and enrichment of Chinese shale gas," Petroleum Exploration and Development, vol. 43, no. 3, pp. 349-359, 2016.

[6] X. Guo, D. Hu, Y. Li, Z. Wei, X. Wei, and Z. Liu, "Geological factors controlling shale gas enrichment and high production in Fuling shale gas field," Petroleum Exploration and Development, vol. 44, no. 4, pp. 513-523, 2017.

[7] X. Guo, Y. Li, T. Borjigen et al., "Hydrocarbon generation and storage mechanisms of deep-water shelf shales of Ordovician Wufeng Formation-Silurian Longmaxi Formation in Sichuan Basin, China," Petroleum Exploration and Development, vol. 47, no. 1, pp. 204-213, 2020.

[8] X. Wei, K. Zhang, Q. Li et al., "Quantitative characterization of pore space for the occurrence of continental shale oil in lithofacies of different types: middle Jurassic Lianggaoshan Formation in southeastern Sichuan Basin of the upper Yangtze area," Geofluids, vol. 2021, Article ID 9906500, 18 pages, 2021.

[9] Z. He, S. Li, H. Nie, Y. Yuan, and H. Wang, "The shale gas "sweet window": "The cracked and unbroken" state of shale and its depth range," Marine and Petroleum Geology, vol. 101, no. 101, pp. 334-342, 2019.

[10] C. Zou, S. Pan, Z. Jing et al., "Shale oil and gas revolution and its impact," Acta Petrolei Sinica, vol. 41, no. 1, pp. 1-12, 2020.

[11] C. Zou, D. Dong, Y. Wang et al., "Shale gas in China: characteristics, challenges and prospects (II)," Petroleum Exploration and Development, vol. 43, no. 2, pp. 182-196, 2016.

[12] C. Zou, D. Dong, Y. Wang et al., "Shale gas in China: characteristics, challenges and prospects (I)," Petroleum Exploration and Development, vol. 42, no. 6, pp. 753-767, 2015.

[13] C. Jia, "Development challenges and future scientific and technological researches in China's petroleum industry upstream," Acta Geologica Sinica, vol. 41, no. 12, pp. 1445-1464, 2020.

[14] T. Guo, "Geological characteristics and exploration prospect of carbonate source rock gas in Sichuan Basin," Journal of Southwest Petroleum University (Science \& Technology Edition), vol. 43 , no. $1,2021$.

[15] C. Jia, "Breakthrough and significance of unconventional oil and gas to classical petroleum geological theory," Petroleum Exploration and Development, vol. 44, no. 1, pp. 1-10, 2017.

[16] Z. Gao and Q. Hu, "Pore structure and spontaneous imbibition characteristics of marine and continental shales in China," AAPG Bulletin, vol. 102, no. 10, pp. 1941-1961, 2018.

[17] Z. Gao, Z. Liang, Qinhong Hu, Z. Jiang, and Q. Xuan, "A new and integrated imaging and compositional method to investigate the contributions of organic matter and inorganic minerals to the pore spaces of lacustrine shale in China," Marine and Petroleum Geology, vol. 127, no. 127, article 104962, 2021.
[18] Z. Gao, X. Yang, C. Hu et al., "Characterizing the pore structure of low permeability Eocene Liushagang Formation reservoir rocks from Beibuwan Basin in northern South China Sea," Marine and Petroleum Geology, vol. 99, no. 99, pp. 107-121, 2019.

[19] S. Zhao, Y. Li, Y. Wang, Z. Ma, and X. Huang, "Quantitative study on coal and shale pore structure and surface roughness based on atomic force microscopy and image processing," Fuel, vol. 244, no. 244, pp. 78-90, 2019.

[20] W. Song, D. Wang, J. Yao et al., "Multiscale image-based fractal characteristic of shale pore structure with implication to accurate prediction of gas permeability," Fuel, vol. 241, no. 241, pp. 522-532, 2019.

[21] J. Bai, Y. Kang, M. Chen et al., "Impact of surface chemistry and pore structure on water vapor adsorption behavior in gas shale," Chemical Engineering Journal, vol. 402, no. 402, article 126238, 2020.

[22] K. Liu, M. Ostadhassan, J. Zhou, T. Gentzis, and R. Rezaee, "Nanoscale pore structure characterization of the Bakken shale in the USA," Fuel, vol. 209, no. 209, pp. 567-578, 2017.

[23] Y. Zhang, B. Yu, Z. Pan, C. Hou, Q. Zuo, and M. Sun, "Effect of thermal maturity on shale pore structure: a combined study using extracted organic matter and bulk shale from Sichuan Basin, China," Journal of Natural Gas Science and Engineering, vol. 74, no. 74, article 103089, 2020.

[24] Y. Li, Z. Wang, Z. Pan, X. Niu, Y. Yu, and S. Meng, "Pore structure and its fractal dimensions of transitional shale: a crosssection from east margin of the Ordos Basin, China," Fuel, vol. 241, no. 241, pp. 417-431, 2019.

[25] D. Feng, X. Li, X. Wang et al., "Water adsorption and its impact on the pore structure characteristics of shale clay," Applied Clay Science, vol. 155, no. 155, pp. 126-138, 2018.

[26] W. Ji, Y. Song, Z. Jiang et al., "Micro-nano pore structure characteristics and its control factors of shale in Longmaxi Formation, southeastern Sichuan Basin," Acta Petrolei Sinica, vol. 37, no. 2, pp. 182-195, 2016.

[27] T. Li, Z. Jiang, Z. Li et al., "Continental shale pore structure characteristics and their controlling factors: a case study from the lower third member of the Shahejie Formation, Zhanhua Sag, Eastern China," Journal of Natural Gas Science and Engineering, vol. 45, no. 45, pp. 670-692, 2017.

[28] T. Li, Z. Jiang, C. Xu et al., "Effect of pore structure on shale oil accumulation in the lower third member of the Shahejie Formation, Zhanhua Sag, eastern China: evidence from gas adsorption and nuclear magnetic resonance," Marine and Petroleum Geology, vol. 88, no. 88, pp. 932-949, 2017.

[29] P. Wang, Z. Jiang, P. Li, C. Jin, X. Li, and P. Huang, "Organic matter pores and evolution characteristics of shales in the Lower Silurian Longmaxi Formation and the Lower Cambrian Niutitang Formation in periphery of Chongqing," Natural Gas Geoscience, vol. 29, no. 7, pp. 997-1008, 2018.

[30] C. Ning, Z. Jiang, Z. Gao et al., "Characteristics and controlling factors of reservoir space of mudstone and shale in Es3x in the Zhanhua Sag," Marine and Petroleum Geology, vol. 88, no. 88, pp. 214-224, 2017.

[31] C. Ning, Z. Ma, Z. Jiang et al., "Effect of shale reservoir characteristics on shale oil movability in the lower third member of the Shahejie Formation, Zhanhua Sag," Acta Geologica Sinica-English Edition, vol. 94, no. 2, pp. 352-363, 2020.

[32] J. Li, S. Tao, Z. Wang, C. Zou, X. Gao, and S. Wang, "Characteristics of Jurassic petroleum geology and main factors of 
hydrocarbon accumulation in NE Sichuan basin," Natural Gas Geoscience, vol. 5, 2010.

[33] Y. Qing, Z. Lü, J. Wu et al., "Formation mechanisms of calcite cements in tight sandstones of the Jurassic Lianggaoshan Formation, northeastern Central Sichuan Basin," Australian Journal of Earth Sciences, vol. 66, no. 5, pp. 723-740, 2019.

[34] J. Zou, T. Jin, X. Li, T. Wei, R. Guo, and R. Bai, "Evaluation on exploration potentials of lower Jurassic reservoirs in eastern Sichuan Basin," China Petroleum Exploration, vol. 23, no. 4, p. 30, 2018.

[35] X. Wang, S. He, X. Guo, B. Zhang, and X. Chen, “The resource evaluation of Jurassic shale in North Fuling area, eastern Sichuan Basin, China," Energy \& Fuels, vol. 32, no. 2, pp. 1213-1222, 2018.

[36] C. Zou, S. Tao, Y. Fan, and X. Gao, "Characteristics of hydrocarbon accumulation and distribution of tight oil in China: an example of Jurassic tight oil in Sichuan Basin," AAPG Search and Discovery, vol. 10386, pp. 1-6, 2012.

[37] Z. Pang, S. Tao, Q. Zhang et al., "Enrichment factors and sweep spot evaluation of Jurassic tight oil in Central Sichuan Basin, SW China," Petroleum Research, vol. 4, no. 4, pp. 334347, 2019.

[38] K. Zhang, Y. Song, S. Jiang et al., "Mechanism analysis of organic matter enrichment in different sedimentary backgrounds: a case study of the Lower Cambrian and the Upper Ordovician-Lower Silurian, in Yangtze region," Marine and Petroleum Geology, vol. 99, no. 2019, pp. 488-497, 2019.

[39] K. Zhang, J. Peng, W. Liu et al., "The role of deep geofluids in the enrichment of sedimentary organic matter: a case study of the Late Ordovician-Early Silurian in the upper Yangtze region and early Cambrian in the lower Yangtze region, South China," Geofluids, vol. 2020, Article ID 8868638, 12 pages, 2020.

[40] K. Zhang, Z. Jiang, L. Yin et al., "Controlling functions of hydrothermal activity to shale gas content-taking lower Cambrian in Xiuwu Basin as an example," Marine and Petroleum Geology, vol. 85, no. 2017, pp. 177-193, 2017.

[41] S. Su, Z. Jiang, S. Xuanlong et al., "The effects of shale pore structure and mineral components on shale oil accumulation in the Zhanhua Sag, Jiyang Depression, Bohai Bay Basin, China," Journal of Petroleum Science and Engineering, vol. 165, no. 165, pp. 365-374, 2018.

[42] T. Li, Z. Jiang, P. Su et al., "Effect of laminae development on pore structure in the lower third member of the Shahejie Shale, Zhanhua Sag, EEastern China," Interpretation, vol. 8, no. 1, pp. T103-T114, 2020.

[43] E. Wang and B. Burchfiel, "Late Cenozoic to Holocene deformation in southwestern Sichuan and adjacent Yunnan, China, and its role in formation of the southeastern part of the Tibetan Plateau," Geological Society of America Bulletin, vol. 112, no. 3, pp. 413-423, 2000.

[44] L. Chen, Y. Lu, S. Jiang, J. Li, T. Guo, and C. Luo, "Heterogeneity of the Lower Silurian Longmaxi marine shale in the Southeast Sichuan Basin of China," Marine and Petroleum Geology, vol. 65, no. 65, pp. 232-246, 2015.

[45] P. Zhang, "A review on active tectonics and deep crustal processes of the Western Sichuan region, eastern margin of the Tibetan Plateau," Tectonophysics, vol. 584, no. 584, pp. 7-22, 2013.

[46] H. Guo, S. Liu, J. He, P. Zhu, and Q. L. Zhang, "Hydrocarbon pooling conditions of the Jurassic Lianggaoshan Formation in
Guangan area, central Sichuan Basin," Natural Gas Industry, vol. 28 , no. 4 , p. $37,2008$.

[47] Z. C. Wang, W. Z. Zhao, Z. Y. Li, X. F. Jiang, and J. Li, "Role of basement faults in gas accumulation of Xujiahe Formation, Sichuan Basin," Petroleum Exploration and Development, vol. 35, no. 5, pp. 541-547, 2008.

[48] C. Li, D. He, G. Lu, K. Wen, A. Simon, and Y. Sun, "Multiple thrust detachments and their implications for hydrocarbon accumulation in the northeastern Sichuan Basin, southwestern China," AAPG Bulletin, vol. 105, no. 2, pp. 357-390, 2021.

[49] K. Su, J. Lu, G. Zhang et al., "Origin of natural gas in Jurassic Da'anzhai member in the western part of central Sichuan Basin, China," Journal of Petroleum Science and Engineering, vol. 167, no. 167, pp. 890-899, 2018.

[50] X. Lu, M. Li, X. Wang et al., Distribution and Geochemical Significance of Rearranged Hopanes in Jurassic Source Rocks and Related Oils in the Center of the Sichuan Basin, China, ACS omega, 2021.

[51] Z. Liu, G. Liu, Z. Hu et al., "Lithofacies types and assemblage features of continental shale strata and their implications for shale gas exploration: a case study of the Middle and Lower Jurassic strata in the Sichuan Basin," Natural Gas Industry B, vol. 7, no. 4, pp. 358-369, 2020.

[52] X. Tang, Z. Jiang, S. Jiang, L. Cheng, and Y. Zhang, "Characteristics and origin of in-situ gas desorption of the Cambrian Shuijingtuo Formation shale gas reservoir in the Sichuan Basin, China," Fuel, vol. 187, no. 187, pp. 285-295, 2017.

[53] P. Wang, Z. Jiang, L. Chen et al., "Pore structure characterization for the Longmaxi and Niutitang shales in the Upper Yangtze Platform, South China: evidence from focused ion beam-He ion microscopy, nano-computerized tomography and gas adsorption analysis," Marine and Petroleum Geology, vol. 77, no. 77, pp. 1323-1337, 2016.

[54] P. Wang, Z. Jiang, W. Ji et al., "Heterogeneity of intergranular, intraparticle and organic pores in Longmaxi shale in Sichuan Basin, South China: evidence from SEM digital images and fractal and multifractal geometries," Marine and Petroleum Geology, vol. 72, no. 72, pp. 122-138, 2016.

[55] W. Ji, Y. Song, Z. Jiang et al., "Estimation of marine shale methane adsorption capacity based on experimental investigations of Lower Silurian Longmaxi formation in the Upper Yangtze Platform, South China," Marine and Petroleum Geology, vol. 68, pp. 94-106, 2015.

[56] W. Ji, Y. Song, Z. Jiang et al., "Fractal characteristics of nanopores in the Lower Silurian Longmaxi shales from the Upper Yangtze Platform, South China," Marine and Petroleum Geology, vol. 78, pp. 88-98, 2016.

[57] W. Ji, Y. Song, Z. Jiang, X. Wang, Y. Bai, and J. Xing, "Geological controls and estimation algorithms of lacustrine shale gas adsorption capacity: a case study of the Triassic strata in the southeastern Ordos Basin, China," International Journal of Coal Geology, vol. 134-135, pp. 61-73, 2014.

[58] K. Zhang, Y. Song, S. Jiang et al., "Shale gas accumulation mechanism in a syncline setting based on multiple geological factors: an example of southern Sichuan and the Xiuwu Basin in the Yangtze region," Fuel, vol. 241, no. 2019, pp. 468-476, 2019.

[59] K. Zhang, J. Peng, X. Wang et al., "Effect of organic maturity on shale gas genesis and pores development: a case study on marine shale in the upper Yangtze region, South China," Open Geosciences, vol. 12, no. 1, pp. 1617-1629, 2020. 
[60] B. Liu, S. He, L. Meng, X. Fu, L. Gong, and H. Wang, "Sealing mechanisms in volcanic faulted reservoirs in Xujiaweizi extension, Northern Songliao Basin, Northeastern China," AAPG Bulletin, vol. 105, no. 8, pp. 1721-1743, 2021.

[61] B. Liu, J. Sun, Y. Zhang et al., "Reservoir space and enrichment model of shale oil in the first member of Cretaceous Qingshankou Formation in the Changling Sag, southern Songliao Basin, NE China," Petroleum Exploration and Development, vol. 48, no. 3, pp. 608-624, 2021.

[62] H. Huang, R. Li, Z. Jiang, J. Li, and L. Chen, "Investigation of variation in shale gas adsorption capacity with burial depth: insights from the adsorption potential theory," Journal of Natural Gas Science and Engineering, vol. 73, no. 73, article 103043, 2020.

[63] K. Zhang, Y. Song, C. Jia et al., "Vertical sealing mechanism of shale and its roof and floor and effect on shale gas accumulation, a case study of marine shale in Sichuan Basin, the Upper Yangtze area," Journal of Petroleum Science and Engineering, vol. 175, no. 2019, pp. 743-754, 2019.

[64] K. Zhang, C. Jia, Y. Song et al., "Analysis of Lower Cambrian shale gas composition, source and accumulation pattern in different tectonic backgrounds: a case study of Weiyuan Block in the Upper Yangtze region and Xiuwu Basin in the Lower Yangtze region," Fuel, vol. 263, no. 2020, article 115978, 2020.

[65] P. Wang, Z. Jiang, L. Yin et al., "Lithofacies classification and its effect on pore structure of the Cambrian marine shale in the Upper Yangtze Platform, South China: evidence from FE-SEM and gas adsorption analysis," Journal of Petroleum Science and Engineering, vol. 156, no. 2017, pp. 307-321, 2017.

[66] K. Zhang, Z. Li, S. Jiang et al., "Comparative analysis of the siliceous source and organic matter enrichment mechanism of the Upper Ordovician-Lower Silurian shale in the UpperLower Yangtze area," Minerals, vol. 8, no. 7, p. 283, 2018.

[67] K. Zhang, Z. Jiang, X. Xie et al., "Lateral percolation and its effect on shale gas accumulation on the basis of complex tectonic background," Geofluids, vol. 2018, Article ID 5195469, 11 pages, 2018.

[68] K. Zhang, Y. Song, S. Jiang et al., "Accumulation mechanism of marine shale gas reservoir in anticlines: a case study of the southern Sichuan Basin and Xiuwu Basin in the Yangtze region," Geofluids, vol. 2019, Article ID 5274327, 14 pages, 2019.

[69] R. Wang, Z. Hu, L. Dong et al., "Advancement and trends of shale gas reservoir characterization and evaluation," Oil \& Gas Geology, vol. 42, no. 1, pp. 54-65, 2021.

[70] R. Wang, S. Long, Y. Peng, and Y. Ju, "Characteristics of organic matter particles and organic pores of shale gas reservoirs: a case study of Longmaxi-Wufeng Shale, Eastern Sichuan Basin," Natural Gas Industry, vol. 10, no. 2, 2020.

[71] J. Chen, L. Wang, C. Wang, B. Yao, Y. Tian, and Y. S. Wu, "Automatic fracture optimization for shale gas reservoirs based on gradient descent method and reservoir simulation," Advances in Geo-Energy Research, vol. 5, no. 2, pp. 191-201, 2021.

[72] Z. Gao, Y. Fan, Q. Xuan, and G. Zheng, "A review of shale pore structure evolution characteristics with increasing thermal maturities," Advances in Geo-Energy Research, vol. 4, no. 3, pp. 247-259, 2020.

[73] R. Wang, Z. Hu, S. Long et al., "Differential characteristics of the Upper Ordovician-Lower Silurian Wufeng-Longmaxi shale reservoir and its implications for exploration and development of shale gas in/around the Sichuan Basin," Acta Geologica Sinica-English Edition, vol. 93, no. 3, pp. 520-535, 2019. 